\title{
USING AN AERIAL SYSTEM OF REMOTE SENSING TO DETECT DIFFERENT NUTRITIONAL STATUS IN Brachiaria decumbens
}

\author{
MÁRIO C. DA SILVA JÚNIOR ${ }^{2}$, FRANCISCO DE A. DE C. PINTO ${ }^{3}$, DANIEL M. DE \\ QUEIROZ $^{3}$, LUCIANO B. VIEIRA ${ }^{3}$, RICARDO C. DE RESENDE ${ }^{4}$
}

\begin{abstract}
The aim of this study was to use digital images acquired by cameras attached to a helium balloon to detect variation of the nutritional status in Brachiaria decumbens. The treatments consisted of five doses of nitrogen $\left(0,50,100,150\right.$ e $\left.200 \mathrm{~kg} \mathrm{ha}^{-1}\right)$ with six replications each, evaluated in a completely randomized statistical design. A remote sensing system composed of digital cameras and microcomputers was used for image acquisition, and a helium balloon lifted the cameras to the heights of 15, 20, 25 and 30m. A portable chlorophyll meter and analyses of leaf nitrogen content were used to make comparisons with data obtained by the remote sensing system. Data was acquired in two phases, in different climatic conditions. At the end of each phase, dry matter production was measured. Three vegetation indices were used to evaluate the detection of different nutritional status. The three indices were able to detect the effects of $\mathrm{N}$ doses. The indices constructed with the Green spectral band showed to be more efficient.
\end{abstract}

KEYWORDS: digital images, vegetation indices, nitrogen.

\section{UTILIZAÇÃO DE UM SISTEMA AÉREO DE SENSORIAMENTO REMOTO PARA DETECTAR DIFERENTES STATUS NUTRICIONAIS EM Brachiaria decumbens}

RESUMO: O objetivo deste trabalho foi utilizar imagens digitais adquiridas por câmeras acopladas em um balão a gás hélio para detectar variação nos status nutricionais em Brachiaria decumbens. Os tratamentos consitiram em cinco doses de nitrogênio (0;50;100; 150 e $200 \mathrm{~kg} \mathrm{ha}^{-1}$ ) com 6 repetições cada, avaliados em delineamento inteiramente casualizado. Para a aquisição das imagens, foi utilizado um sistema de sensoriamento remoto composto por câmeras digitais e microcomputadores, utilizando um balão a gás hélio, para levantamento das câmeras nas alturas de 15; 20; 25 e $30 \mathrm{~m}$. Também se utilizou de um medidor de clorofila portátil e análise do teor de nitrogenio foliar para efetuar comparações com os dados obtidos pelo sistema de sensoriamento remoto. Os dados foram adquiridos em duas fases, em condições climáticas distintas. Ao final de cada fase, foi medida a produtividade de matéria seca. Foram utilizados três índices de vegetação para avaliar a detecção dos diferentes status nutricionais. Os três índices foram capazes de detectar os efeitos das doses de N. Os índices formados com a banda verde mostraram-se mais eficientes.

PALAVRAS-CHAVE: imagens digitais, índices de vegetação, nitrogênio.

\section{INTRODUCTION}

Brazil stands out as a global exporter of bovine meat, possessing good international competitiveness, and the major cause of this is that the cost of production is relatively lower because the animal feeding is predominantly by pasture (SOBER, 2011).

The pastures occupy most of the agricultural areas of Brazil, however, the growing advancement of agriculture on pasture areas in recent years is making the production of milk and meat move to regions of poor soils, inadequate to agriculture. In addition, the financial advantages

\footnotetext{
${ }^{1}$ Parte da Dissertação de Mestrado do primeiro autor. Projeto financiado pela FAPEMIG.

${ }^{2}$ Eng $^{\circ}$ de Controle e Automação, Professor Doutor, Departamento das Engenharias de Telecomunicações e Mecatrônica, UFSJ/Ouro

Branco - MG, mariocupertino@ufsj.edu.br.

${ }^{3}$ Eng $^{\circ}$ Agrícola, Professor Associado, Departamento de Engenharia Agrícola, UFV/Viçosa - MG.

${ }^{4}$ Eng $^{\circ}$ Mecânico, Professor Associado, Departamento de Engenharia de Produção e Mecânica, UFV/Viçosa - MG.

Recebido pelo Conselho Editorial em: 16-2-2012
}

Aprovado pelo Conselho Editorial em: 218-3-2013 
of agriculture have been demanding the cattle breeders to increase the productivity and competitiveness of the exploration to enable livestock on agricultural land. Therefore, it increases the need for greater forage production in an ever more limited space and less favorable conditions (BARCELLOS et al., 2008).

Among the factors or practices of pasture management that have provided increased forage productivity, ability of animal support in the property and improvement of economic performance, we highlight the use of fertilizers, especially nitrogen (FAGUNDES et al., 2011). On the other hand, the use of nitrogen fertilizers should be performed optimally and economically feasible in order to reduce pressure on the environment. Thus, to increase productivity, rational management of nitrogen fertilizer will have a key role in the sustainable development of livestock.

The development of forage is variable along the pasture area, mainly due to the variability of nutritional availability and physical and chemical properties of the soil. Thus, identifying this variability during plant development may allow diagnosis of causes that could still be corrected in a timely manner to optimize productivity (SAMBORSKI et al., 2009), inserting in the concept of precision agriculture.

In order to study ways to identify nutritional status related to nitrogen in different cultures, in a practical and less costly way, some studies have been developed. Equipment, such as portable chlorophyll meters, estimate the amount of chlorophyll present in the plant, and this value is proportional to the nitrogen content, but this method requires physical contact with the leaves during its operation. There are other promising methods, such as the remote sensing techniques, which also capture spectral information of pigments of plants through sensors, but without contact with it, using the reflectance of the crop.

SILVA JÚNIOR et al. (2008) built a system for terrestrial remote sensing to detect different nutritional status through vegetation indices, caused by the variation of nitrogen doses in an area planted with Brachiaria decumbens. The results showed that the indices allowed the detection of effects of $\mathrm{N}$ doses in forage. This land system was developed with the intention to be coupled in agricultural machinery and to use its movement to capture images and make the nutritional mapping. In the present work, we intend with an aerial system of remote sensing to acquire and work with images that portray larger areas without having to rely on the use of machinery to move through the area.

Thus, in the present study, we evaluated the possibility to discriminate the effects of different doses of nitrogen fertilizer through vegetation indices, using an aerial remote sensing system, and, thus, to evaluate the correlation and efficiency of this method with regards to other methods already widely used, as the chlorophyll meter and analyses of leaf $\mathrm{N}$ content.

Thus, the general objective of this work was the use of an aerial remote sensing system to detect different nutritional status relative to nitrogen application in Brachiaria decumbens and to correlate vegetation indices with the values obtained with a portable chlorophyll meter and the levels of leaf nitrogen obtained in the laboratory.

\section{MATERIAL AND METHODS}

The experiment was established in the Forage Section, Department of Animal Science, Federal University of Viçosa, in Viçosa city - Minas Gerais (MG) state, in Brazil, in an area of pasture established with Brachiaria decumbens.

Initially, we perfomed the demarcation of the experimental area and the soil sampling, and, from the results of chemical (micro and macronutrients) and physical (texture) analysis of the soil samples, we applied, $50 \mathrm{~kg} \mathrm{ha}^{-1}$ of simple superphosphate (CANTARUTTI et al., 1999), distributed evenly across the experimental area. To the standardization of signalgrass plants, mowing was performed at $10 \mathrm{~cm}$ tall, with removal of overlapped forage of the area. 
The treatments consisted of five doses of nitrogen $\left(0,50,100,150\right.$ and $\left.200 \mathrm{~kg} \mathrm{ha}^{-1}\right)$ applied in the form of urea, and they were evaluated in a completely randomized design with six replications, totaling 30 plots of $3 \times 3 \mathrm{~m}$.

To perform data acquisition in the experimental area, we implemented a remote sensing system that integrated image acquisition with digital cameras, cables, frame grabber card and portable microcomputers, to a helium balloon to lift the cameras in four different height, 15, 20, 25 and $30 \mathrm{~m}$.

After the nitrogen fertilization, the first phase of data acquisition began obtaining digital images at 28 days after fertilization (DAF). At 32 DAF, there were estimates of chlorophyll content using a SPAD 502 chlorophyll meter (Minolta Corporation, Japan) and removed leafs for analysis of leaf $\mathrm{N}$ content in the laboratory. And also at $32 \mathrm{DAF}$ was done cutting the plants at a $20 \mathrm{~cm}$ height of soil in an area of $1 \mathrm{~m}^{2}$ within each plot to measure dry matter yield. After the harvest, the forage was weighed and removed a sub-sample of 300 to $500 \mathrm{~g}$ of grass that was placed in paper bags, also weighed and taken to an oven at $65^{\circ} \mathrm{C}$ for 72 hours. After drying, the samples were weighed again and so it was obtained dry matter produced. After cutting, the unharvested area of the portion (border) was also cut at a $20 \mathrm{~cm}$ height and we began the second phase of data acquisition, with reapplication of the same nitrogen doses added to $60 \mathrm{~kg} \mathrm{ha}^{-1}$ of potassium chloride in all plots.

Due to the time change observed in the second phase, with reduced rainfall, light and temperature, the response of plants to fertilization occurred more slowly, thereat image acquisition occurred at $51 \mathrm{DAF}$, and the estimates of chlorophyll with SPAD and the leaves for analysis of leaf nitrogen content were obtained at 53 DAF. At 53 DAF, we performed again the cutting of the plants to measure the dry matter yield, using the same procedures reported previously.

Measurements of chlorophyll estimates with SPAD were scheduled to be held on the next day of image acquisition. However, due to operational and climatic problems, measurements of chlorophylls were performed at 4 and 2 days after images for the first and second phases of the experiment, respectively.

Images acquired at 28 DAF were held from 3:00 pm on open air conditions. The images at 51 DAF were collected in open air conditions, between 10:00 am and 2:00 pm and in the presence of sunlight. Weeds were controlled manually in all plots when necessary.

The remote sensing system for data collection consisted of a balloon inflated with helium gas and a system of image acquisition, coupled to a remote system of data communication. Figure 1(a) illustrates the layout of the remote sensing system using the balloon. Figure 1(b) illustrates the remote sensing system capturing the images of the plots in the experimental area. Figures 1(c) and 1(d) illustrate, respectively, the provision of equipment inside the gondola and the plots in the experimental area at 30m high.

An aluminum gondola was built, which was tied to the balloon, where all the necessary equipment for image acquisition were allocated.

The balloon used was a "blimp" type, spherical, with a diameter of $4 \mathrm{~m}$, with a maximum capacity of approximately $33 \mathrm{~m}^{3}$ of helium gas, providing a buoyant force sufficient to lift all equipment, which together weighed approximately $12 \mathrm{~kg}$. The balloon was wrapped by 12 ropes of $3 \mathrm{~mm}$ diameter, which passed through moorings attached to the balloon and were connected at both ends forming a cage. 


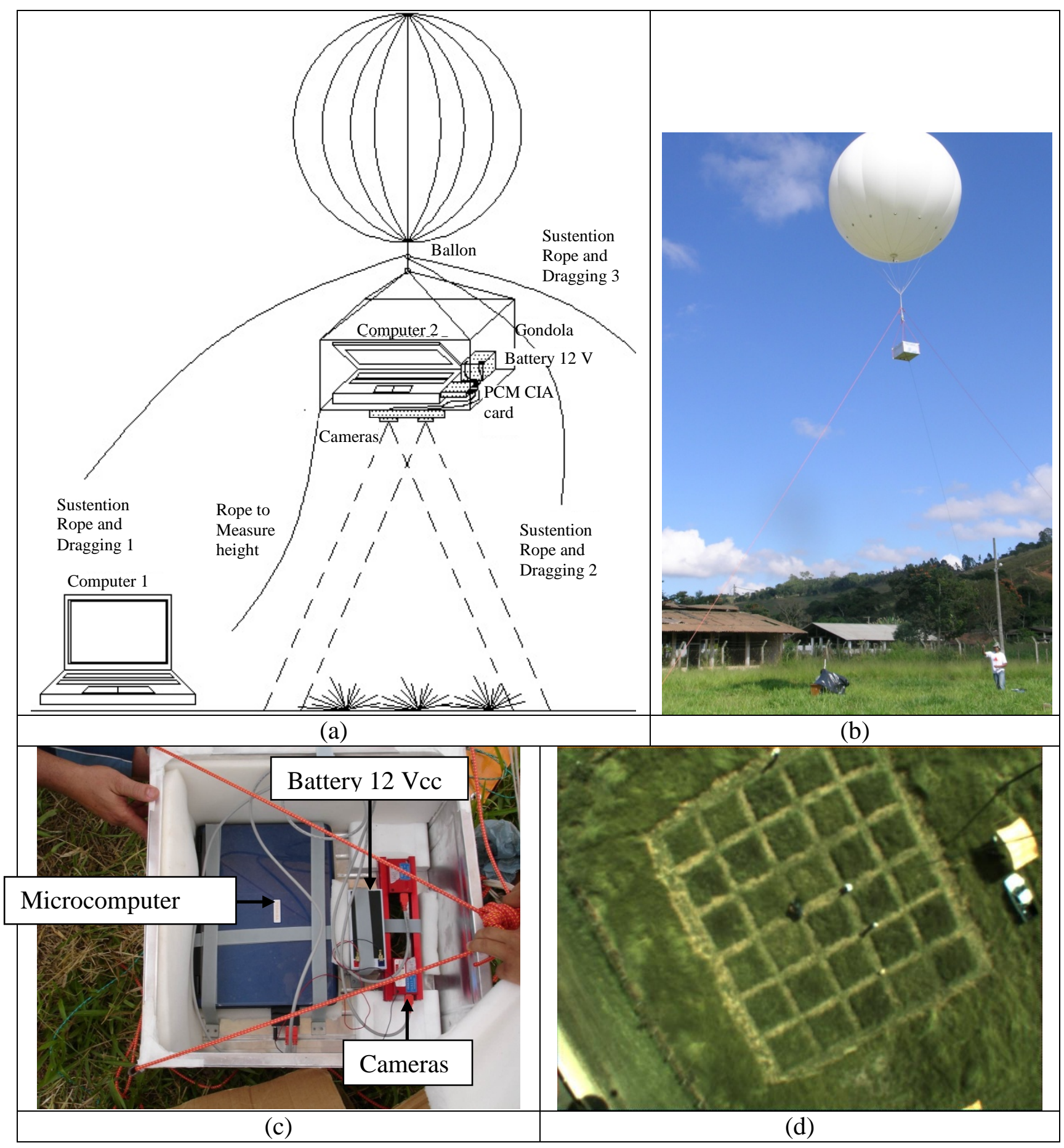

FIGURE 1. Scheme of the remote sensing system using the balloon with helium gas (a), remote sensing system capturing images of experimental area (b), the provision of equipment to acquire images inside the gondola (c), and experimental plots in the experimental area imaged by remote sensing system at 30 meters high (d).

To make the sustention and dragging of the balloon across the area, we used three ropes of $5 \mathrm{~mm}$, and 35m long. They were attached to the bottom end of the balloon, between two nodes, so that any force applied by the ropes in either direction was evenly distributed throughout the balloon, and that the balloon movement was controlled in the desired direction.

To measure the height of the cameras, we used a fourth rope of 3mm graded 5 by $5 \mathrm{~m}$, attached to the gondola, which also served to stabilize the movement of the gondola and get images with good positioning of the plots. 
The image acquisition system used was STH-DCSG-VAR/-C stereo head of Videre Design Manufacturer (California, USA). This system consisted of two cameras, one with a monochrome sensor and another sensor with three bands (blue, green and red), $13.5 \mathrm{~cm}$ apart, which captured two images, simultaneously, in the same scene.

In monochrome sensor camera, we coupled an optical filter, high-pass type, which limited the range of the electromagnetic spectrum corresponding to near-infrared (NIR). The filter allowed passing the energy above the wavelength of 695nm.

The spectrum bands that sensitized the sensor of the other camera, according to VIDERE DESIGN (2005), are between 390 and 530nm, with a sensitivity peak situated at approximately $470 \mathrm{~nm}$ for the blue band (B), between 490 and $610 \mathrm{~nm}$ with a peak at about $540 \mathrm{~nm}$ for the green band (G), and between 590 and 750nm with a peak at about $620 \mathrm{~nm}$ for the red band (R).

The exposure and gain time of the cameras were adjusted to 50 and 17 , respectively. These values are in percentage and were chosen based on preliminary tests, avoiding the saturation of the values of pixels. Focus adjustment was also maintained the same during all image acquisitions, positioned at infinity of the lens. The lens diaphragm was set before the start of image acquisition, and as there was no numbering in the equipment, adjustment was made by analyzing the image formed in the computer by focusing on the target (portion) and observing the effect noise (pixel saturation) by the amount of light.

For operation of the cameras, it was required external power, therefore a battery of 12 volts was coupled to the PCMCIA card. The pattern of the lenses used was C-mount with focal length of $2.8 \mathrm{~mm}$. The images were saved in BMP (Bitmap) with dimensions of $480(\mathrm{~W}) \times 640(\mathrm{H})$ pixels, using the software SRI 's Small Vision System (SVS) supplied by the manufacturer of the cameras. The sensor used in the cameras was CMOS MT9V022 imager in the 1/3” format.

The images depicted areas of approximately 388, 690, 1,077 and $1,551 \mathrm{~m}^{2}$ with a spatial resolution of approximately 3.3, 4.3, 5.5, $6.5 \mathrm{~cm} \mathrm{pixel}^{-1}$ for the heights of $15,20,25$ and $30 \mathrm{~m}$, respectively.

It was necessary to use a data communication system to perform the image acquisition. Therefore, we used two portable microcomputers, one remained on the ground and the other was on the gondola. And through a wireless communication system and a software client/server, the computer ashore accessed the camera software on the computer of the gondola, having access to the camera image. The communication system had a radius of action of about $50 \mathrm{~m}$.

Image processing was performed using the software Matlab (The MathWorks, USA) and the image processing toolbox.

As each image framed more than one plot, we cut a block of $30 \times 30$ pixels within each plot for all heights, and from these blocks we calculated vegetation indices. In all the cuts, we respected the border of the plot.

It was considered that the lighting was constant during acquisition; ergo the pixel value was only due to the spectral properties of the object. Thus, during image processing, to make the calculations of the indices, it was considered that the canopy reflectance was equal to the average of the pixels of the block cut.

The images were transformed into vegetation indices based on the numerical values of the pixels of different bands. Thus, we obtained three indices, which are the relation between the two spectrum bands. These vegetation indices were used to enhance the image information about the nutritional status of plants and mitigate the influence of the variability of natural lighting (EPIPHANIO et al., 1996).

The indices studied were NDVI (Normalized Difference Vegetation Index) proposed by ROUSE et al. (1974), GNDVI (Green Normalized Difference Vegetation Index) proposed by 
GITELSON et al. (1996), and SAVI (Soil Adjusted Vegetation Index) proposed by HUETE (1988) according to the Equations 1, 2 and 3, respectively.

$$
\begin{aligned}
& N D V I=\frac{I V-V m}{I V+V m} \\
& G N D V I=\frac{I V-V d}{I V+V d} \\
& S A V I=\frac{I V-V m}{I V+V m+L}(1+L)
\end{aligned}
$$

In which,

Vm - numerical value of the pixel in the red band;

IV - numerical value of the pixel in the near infrared band;

$\mathrm{Vd}$ - numerical value of the pixel in the green band;

L - adjustment Constant.

The coefficient ' $L$ ' chosen was 0.5 , which is the value used for vegetation with intermediate density, and, according to HUETE (1988), this value minimizes the influence of a background soil for a wide range of leaf area index.

Estimates of chlorophyll content were obtained using a SPAD 502 chlorophyll meter, at 32 DAF in the first phase and 53 DAF in the second phase of the experiment. This device measures SPAD values that represent an indirect measure of the content of chlorophyll and therefore can indicate the status of nitrogen, due to the proportionality that nitrogen has in relation to chlorophyll (SOLARI et al., 2008). To perform the measurements, the leaf was positioned between the sender and the receiver of the equipment. Thirty readings were made in the SPAD in each plot, and each value was measured on different leaves along each portion, and the chosen leaves were the newest fully expanded with the device positioned in the intermediate portion of the leaf. After obtaining the 30 values, we calculated the average to represent chlorophyll content of each portion.

In each plot, the same 30 leaves that were used to estimate the chlorophyll content were harvested and placed in paper bags to determine the $\mathrm{N}$ content in the laboratory.

Regression analyzes were performed to check for significant functional relation between the dependent variables (indices) and the independent variable ( $\mathrm{N}$ doses) in all two phases, using the software Matlab (The MathWorks, USA) to develop the algorithms.

Thus, to determine whether there was significant difference between treatments, we applied the $\mathrm{F}$ test for lack of fit and analysis of variance of regression and also tests of model coefficients by $\mathrm{t}$ test, all at $1 \%$ probability. First, we adopted the simple linear regression model; if the $\mathrm{F}$ test for lack of adjustment was significant, the model was considered inappropriate and then we tried to adjust the model of second degree.

Models higher than second degree were not tested, because they do not represent the biological phenomenon of culture, because the response with increasing doses of an element in the plant is linear or quadratic (MALAVOLTA et al., 1986; ALVIM et al., 1998; GARCEZ NETO et al., 2002).

The relation between variables was also assessed by the correlation between indices (NDVI, GNDVI and SAVI) and SPAD values, indices and leaf $\mathrm{N}$ and between indices and dry matter assessed. We also performed the correlation between values of SPAD, leaf $\mathrm{N}$ and dry matter.

\section{RESULTS AND DISCUSSION}

Models of indices that were adjusted in the first phase of this study are presented in Table 1. 
TABLE 1. Models adjusted to the data for each dependent variable and coefficient of determination $\left(R^{2}\right)$ at 28 days after fertilization (DAF) in the first experimental phase in heights of 15, 20, 25 and $30(\mathrm{~m})$.

\begin{tabular}{lc}
\hline \multicolumn{1}{c}{ Adjusted models } & $\mathrm{R}^{2}$ \\
\hline \multicolumn{1}{c}{$15(\mathrm{~m})$} & 0.9330 \\
$\mathrm{NDVI}=0.2545+0.0012 \mathrm{~N}$ & 0.9446 \\
GNDVI $=0.1305+0.0014 \mathrm{~N}$ & 0.8029 \\
$\mathrm{SAVI}=0.1574+0.0007 \mathrm{~N} 20(\mathrm{~m})$ & 0.8242 \\
$\mathrm{NDVI}=0.2839+9.1013 \times 10^{-4} \mathrm{~N}$ & 0.8709 \\
GNDVI $=0.1627+0.0011 \mathrm{~N}$ & 0.8983 \\
$\mathrm{SAVI}=0.1539+0.0016 \mathrm{~N}-5.1200 \times 10^{-6} \mathrm{~N}^{2}$ & \\
$\mathrm{NDVI}=0.2548+0.0011 \mathrm{~N} 25(\mathrm{~m})$ & 0.9017 \\
GNDVI $=0.1365+0.0013 \mathrm{~N}$ & 0.9220 \\
$\mathrm{SAVI}=0.1463+0.0016 \mathrm{~N}-4.9319 \times 10^{-6} \mathrm{~N}^{2}$ & 0.9569 \\
$\mathrm{NDVI}=0.2310+0.0022 \mathrm{~N}-6.5238 \times 10^{-6} \mathrm{~N}^{2}$ & \\
GNDVI $=0.1138+0.0025 \mathrm{~N}-6.6242 \times 10^{-6} \mathrm{~N}^{2}$ & 0.9851 \\
SAVI $=0.1555+0.0015 \mathrm{~N}-4.8962 \times 10^{-6} \mathrm{~N}^{2}$ & 0.9883 \\
\hline
\end{tabular}

NDVI: Normalized Difference Vegetation Index; GNDVI: Green Normalized Difference Vegetation Index; SAVI: Soil Adjusted Vegetation Index; The coefficients $\beta_{1}$ and $\beta_{2}$ of the adjusted models were significant at level of $1 \%$ probability by t "student" test.

It is observed that at $30 \mathrm{~m}$ high all indices were adjusted to linear models of the second degree, i.e., there was a decrease in the increment of index values in relation to the increase of $\mathrm{N}$ doses applied. This tendency to saturation of indices in larger doses may have been for two reasons: the saturation due to high index of leaf area of the canopy in higher doses (WALTER-SHEA et al., 1997; WU et al., 2008); or the plant has reached the region of nutrients excess, with nutritional imbalance (MALAVOLTA et al., 1986; DOUGHERTY \& RHYKERD, 1985). However, in this study, this tendency to saturation was observed only at $30 \mathrm{~m}$ high. At 25 and $20 \mathrm{~m}$ only SAVI index adjusted the linear model of second degree, and at $15 \mathrm{~m}$ all indices adjusted to linear models of first degree.

These results show that the SAVI index from the height of $20 \mathrm{~m}$ obtained a reduction in the increase of its values with increasing doses of $\mathrm{N}$, leading to saturation values . However the GNDVI and NDVI, except at 30m high, did not reach saturation at higher doses, showing greater ease in differentiating the different doses. The higher the altitude, the lower the spatial resolution of the image and, hence, the greater the effect of soil and plant mixture at the numeric value of each pixel. The highest values of leaf area index probably occurred at higher doses of $\mathrm{N}$, saturating vegetation indices due to the effect of multiple reflectance that occurs inside the canopy (GITELSON, 2004). Therefore, a lower spatial resolution in the greatest height enhanced this effect of the canopy at the numerical value of the pixel.

Failure to perform a radiometric correction, transforming the numerical values of the pixels in reflectance, may also have contributed to the different behavior of the indices for the different heights.

Observing only the indices that adjusted linear models of first degree, the GNDVI tended to higher values of coefficient of determination and to highest values of the angular coefficient. The greater the angular coefficient presented on the model of GNDVI in relation to the NDVI is seen as an advantage, because the GNDVI would present a greater variation per unit of variation of $\mathrm{N}$ dose, which would facilitate differentiation between doses of $\mathrm{N}$. Other authors have also identified that 
GNDVI was more sensitive than NDVI to identify different rates of chlorophyll concentration in other plant species (GITELSON et al., 1996).

Figures 2 and 3 illustrate adjusted models to the values of the index GNDVI depending on the $\mathrm{N}$ doses in heights of 25 and 30m, respectively, which represented the two types of behavior of the data found in this study phase.

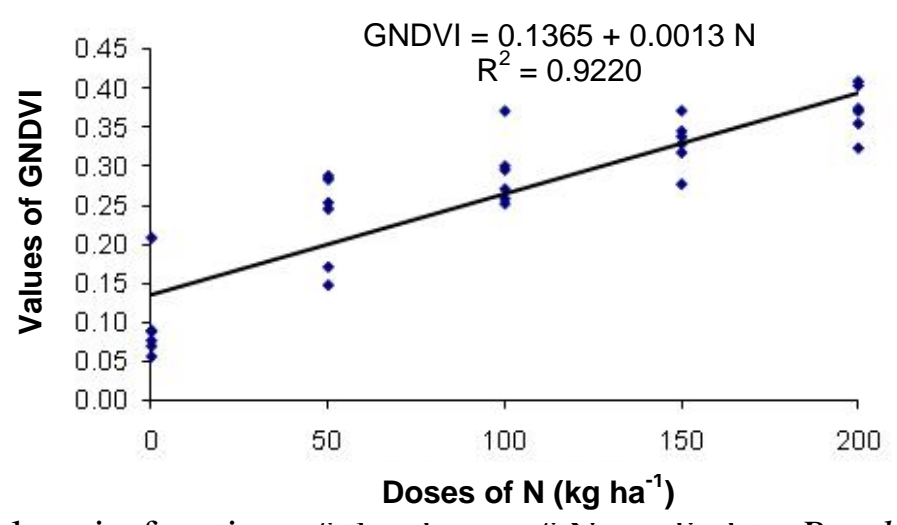

FIGURE 2. GNDVI values in function of the doses of $\mathrm{N}$ applied to Brachiaria decumbens at 28 days after fertilization (DAF) at 25 (m) high in the first phase.

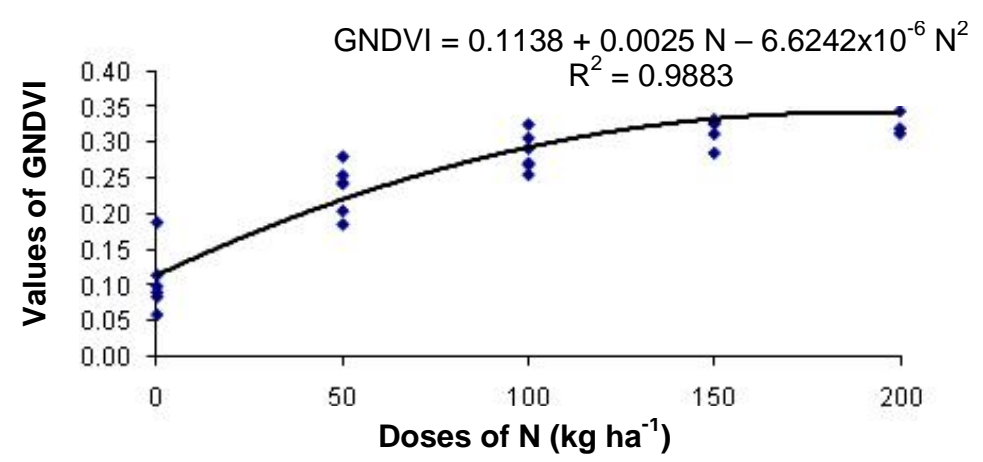

FIGURE 3. GNDVI values in function of the doses of $\mathrm{N}$ applied to Brachiaria decumbens at 28 days after fertilization (DAF) at 30 (m) high in the first phase.

Through the derived of the model of GNDVI index, illustrated by Figure 3, it is possible to estimate that the values of this index tended to stabilize after the dose $188.70 \mathrm{~kg} \mathrm{ha}^{-1}$ of $\mathrm{N}$. This fact of tendency of stabilization of this index values was also observed in other studies of spectral behavior of plants (SERRANO et al., 2000; RAMBO et al., 2010; PONZONI \& SHIMABUKURO, 2007). The authors found that the increase of biomass leads to the saturation in index values, decreasing the response of the indices with the advancement of the plant development. Therefore, this explanation justifies this trend of stabilization of index values with the increase in doses of $\mathrm{N}$, since this increase resulted in an increase in the number of leaves, and the height increase provided a more uniform view of portions, reducing the influence of the shadows of their own leaves and of the background soil.

Table 2 shows the correlation coefficients of index values in relation to SPAD, leaf $\mathrm{N}$ and dry matter acquired at $32 \mathrm{DAF}$. 
TABLE 2. Correlations between vegetation indices obtained at 15, 20, 25 and 30 (m) high at 28 days after fertilization (DAF) and the values of SPAD, leaf $\mathrm{N}$ and dry matter produced (DM) at 32 DAF.

\begin{tabular}{cccc}
\hline INDICES & SPAD & Leaf N & DM $\left(\mathrm{t} \mathrm{ha}^{-1}\right)$ \\
\hline NDVI & $0.78^{* *}$ & $15(\mathrm{~m})$ & $0.65^{* *}$ \\
GNDVI & $0.81^{* *}$ & $0.65^{* *}$ & $0.66^{* *}$ \\
SAVI & $0.77^{* *}$ & $0.62^{* *}$ & $0.62^{* *}$ \\
NDVI & $0.78^{* *}$ & $20(\mathrm{~m})$ & \\
GNDVI & $0.83^{* *}$ & $0.63^{* *}$ & $0.66^{* *}$ \\
SAVI & $0.72^{* *}$ & $0.66^{* *}$ & $0.70^{* *}$ \\
NDVI & $0.56^{* *}$ & $0.64^{* *}$ \\
GNDVI & $0.88^{* *}$ & $0.69^{* *}$ & $0.77^{* *}$ \\
SAVI & $0.90^{* *}$ & $0.71^{* *}$ & $0.78^{* *}$ \\
& $0.83^{* *}$ & $0.64^{* *}$ & $0.82^{* *}$ \\
NDVI & $0.90^{* *}$ & $0.70(\mathrm{~m})$ & $0.76^{* *}$ \\
GNDVI & $0.92^{* *}$ & $0.73^{* *}$ & $0.76^{* *}$ \\
SAVI & $0.85^{* *}$ & $0.66^{* *}$ & $0.75^{* *}$ \\
\hline
\end{tabular}

** correlation significant at 1\% probability. NDVI: Normalized Difference Vegetation Index; GNDVI: Green Normalized Difference Vegetation Index; SAVI: Soil Adjusted Vegetation Index; SPAD: variable obtained by SPAD chlorophyll meter; leaf N: analysis of leaf $\mathrm{N}$ content; DM: dry matter produced in tons per hectare.

The GNDVI index tended to have the highest correlation values at all heights. The use of the green band was more efficient to identify the variation in nutritional status with the estimation of chlorophyll and leaf N content. GITELSON et al. (1996), when studying the use of the green band in remote sensing of vegetation, showed that GNDVI had sensitivity five times greater than the NDVI to the concentration of chlorophyll.

Another trend observed in Table 2 is the correlation values increase with the increase of height. Measurements were made from the highest to the lowest height, i.e., the highest heights tended to present less shading of the plants themselves, which may have influenced the best results at higher heights. SANDMEIER et al. (1998) report that the shadows generated by the very geometry of plants and areas of the canopy without cover influence the spectral reflectance of the canopy.

In this first phase, the GNDVI index was the most suitable among those studied to detect different nutritional status in Brachiaria decumbens, and may also infer dry matter yield. JU et al. (2010) also found that GNDVI was more sensitive than NDVI to identify different rates of chlorophyll concentration in two species of plants.

SAVI index tended to have lower values of correlation with all studied variables. This index has the same relation between spectral bands of NDVI, however SAVI has a constant L multiplied in its formula, which, according to HUETE (1988), aims to reduce the influence of soil reflectance. As the soil in the plots was fully covered by the forage, its influence on the values of the indices was probably minimized. This may explain the lower correlation of SAVI index with the variables.

In the second experimental phase, i.e., at 51 days after refertilization, the data for the three indices calculated in this system adjusted to the linear model of first degree at almost all heights, except at 25 and 30m with SAVI index, which adjusted the linear model of second degree (Table 3). This again indicates that all indices were able to detect the different effects of doses of $\mathrm{N}$ applied at all heights. 
TABLE 3. Models adjusted to the data for each dependent variable and coefficient of determination $\left(\mathrm{R}^{2}\right)$ at 51 days after fertilization (DAF) in the second experimental phase in heights of 15, 20, 25 and $30(\mathrm{~m})$.

\begin{tabular}{|c|c|}
\hline Adjusted models & $\mathrm{R}^{2}$ \\
\hline \multicolumn{2}{|l|}{$15(\mathrm{~m})$} \\
\hline $\mathrm{NDVI}=0.0343+0.0012 \mathrm{~N}$ & 0.9063 \\
\hline GNDVI $=-0.0510+0.0013 \mathrm{~N}$ & 0.9444 \\
\hline SAVI $=-0.0120+0.0008 \mathrm{~N}$ & 0.8707 \\
\hline \multicolumn{2}{|l|}{$20(\mathrm{~m})$} \\
\hline $\mathrm{NDVI}=0.0060+0.0013 \mathrm{~N}$ & 0.9125 \\
\hline GNDVI $=-0.0773+0.0012 \mathrm{~N}$ & 0.9489 \\
\hline SAVI $=0.0026+0.0009 \mathrm{~N}$ & 0.9013 \\
\hline \multicolumn{2}{|l|}{$25(\mathrm{~m})$} \\
\hline $\mathrm{NDVI}=0.0207+0.0013 \mathrm{~N}$ & 0.8574 \\
\hline GNDVI $=-0.0617+0.0012 \mathrm{~N}$ & 0.8981 \\
\hline SAVI $=-0.0160+0.0020 \mathrm{~N}-5.9162 \times 10^{-6} \mathrm{~N}^{2}$ & 0.9901 \\
\hline \multicolumn{2}{|l|}{$30(\mathrm{~m})$} \\
\hline $\mathrm{NDVI}=0.0374+0.0011 \mathrm{~N}$ & 0.8681 \\
\hline GNDVI $=-0.0441+0.0011 \mathrm{~N}$ & 0.9008 \\
\hline SAVI $=-0.0010+0.0018 \mathrm{~N}-5.2067 \times 10^{-6} \mathrm{~N}^{2}$ & 0.9938 \\
\hline
\end{tabular}

NDVI: Normalized Difference Vegetation Index; GNDVI: Green Normalized Difference Vegetation Index; SAVI: Soil Adjusted Vegetation Index; The coefficients $\beta_{1}$ and $\beta_{2}$ of the adjusted models were significant at the $1 \%$ probability by $\mathrm{t}$ "student" test.

At this phase, SAVI index was the only one which tended to stabilize its values with the increase of doses of $\mathrm{N}$, making it difficult its discrimination between doses. The values of the NDVI and GNDVI indices did not tended to stabilize with the increase of doses of $\mathrm{N}$ in any height tested. This shows the potential of these two indices in the discrimination between all doses. Other authors also observed that the spectral response of forage may be used to discriminate different concentrations of leaf nitrogen (BEERI et al., 2007; XIE et al., 2008; NUMATA et al., 2008; FAVA et al., 2009).

It is possible to observe that the GNDVI index showed coefficient $\beta_{0}$ negative at all heights tested, indicating that, in the absence of application of $\mathrm{N}$, the values of this index obtained in the adjusted equations are negative. This shows that, on average, the digital values of the green band were higher than those of the infrared band in this treatment. Therefore, the reflectance of the energy in the near-infrared band was lower due to lower leaf area index (PONZONI \& SHIMABUKURO, 2007). This fact was observed in the treatment without fertilization and in the experimental phase, where climatic conditions were not favorable to the development of the plant, the day was already shorter and temperature was lower, resulting in a lower plant development, the leaf cover by plot area was low, which led to the reduction in reflectance in the infrared band causing the green band to excel.

Among the models adjusted at first degree, again GNDVI tended to higher values of coefficient of determination $\left(\mathrm{R}^{2}\right)$ at all heights, while the highest value was found at the height of 20m (Figure 4). Regarding the angular coefficient of this index, it obtained the highest value only at 15m high. As for 20 and 25m, NDVI obtained the highest values, indicating that at that heights the variation of doses influenced more their values than GNDVI, despite having lower $\mathrm{R}^{2}$. 


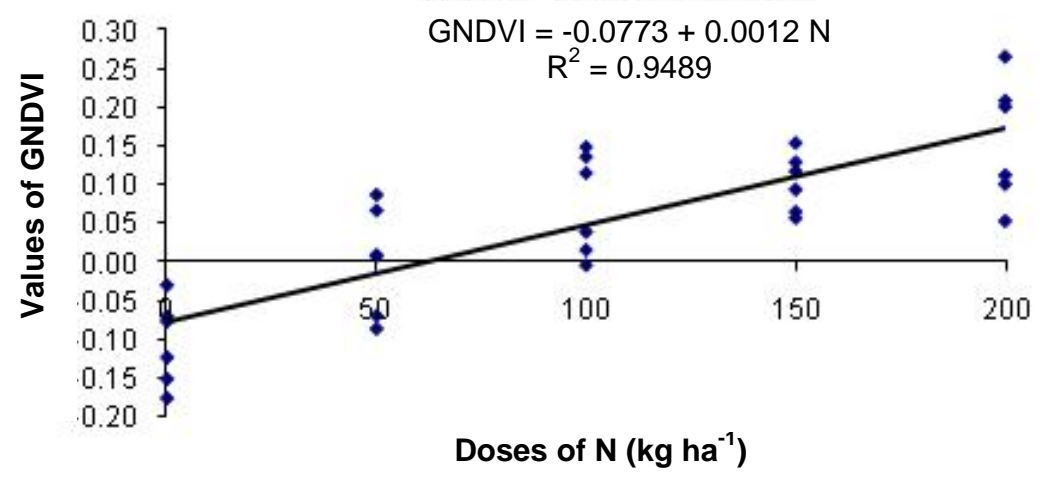

FIGURE 4. GNDVI values in function of the doses of $\mathrm{N}$ applied to Brachiaria decumbens at 51 days after fertilization (DAF) at 20 (m) high in the second phase.

Table 4 shows the correlation coefficients of index values in relation to SPAD, leaf $\mathrm{N}$ and dry matter acquired at $53 \mathrm{DAF}$.

As for the indices in relation to SPAD, the highest values were obtained at $20 \mathrm{~m}$ high; between the leaf $\mathrm{N}$, the highest values were detected at $15 \mathrm{~m}$; and between the dry matter, the highest values were at 30m high. This shows the absence of the trend of correlation values of the indices with the variables in relation to height.

TABLE 4. Correlations between vegetation indices obtained at 15, 20, 25 and 30 (m) high at 51 days after fertilization (DAF) and the values of SPAD, leaf $\mathrm{N}$ and dry matter (DM) produced at 53 DAA.

\begin{tabular}{cccc}
\hline INDICES & SPAD & Leaf N & DM $\left(\mathrm{t} \mathrm{ha}^{-1}\right)$ \\
NDVI & $0.78^{* *}$ & $15(\mathrm{~m})$ & $0.68^{* *}$ \\
GNDVI & $0.79^{* *}$ & $0.65^{* *}$ & $0.69^{* *}$ \\
SAVI & $0.72^{* *}$ & $0.67^{* *}$ & $0.62^{* *}$ \\
NDVI & $0.54^{* *}$ & $0.69^{* *}$ \\
GNDVI & $0.79^{* *}$ & $20(\mathrm{~m})$ & $0.70^{* *}$ \\
SAVI & $0.80^{* *}$ & $0.61^{* *}$ & $0.72^{* *}$ \\
NDVI & $0.80^{* *}$ & $0.62^{* *}$ & $0.69^{* *}$ \\
GNDVI & $0.61^{* *}$ & $0.71^{* *}$ \\
SAVI & $0.77^{* *}$ & $0.7(\mathrm{~m})$ & $0.70^{* *}$ \\
NDVI & $0.78^{* *}$ & $0.59^{* *}$ & $0.72^{* *}$ \\
GNDVI & $0.76^{* *}$ & $0.58^{* *}$ & $0.74^{* *}$ \\
SAVI & $0.78^{* *}$ & $30(\mathrm{~m})$ & $0.73^{* *}$ \\
\hline
\end{tabular}

** correlation significant at 1\% probability. NDVI: Normalized Difference Vegetation Index; GNDVI: Green Normalized Difference Vegetation Index; SAVI: Soil Adjusted Vegetation Index; SPAD: variable obtained by SPAD chlorophyll meter; leaf N: variable obtained by analysis of leaf $\mathrm{N}$ content in the laboratory; DM: dry matter produced in tons per hectare.

By analyzing each height separately, we observe that the GNDVI was the index with trend to higher correlation coefficients with SPAD, leaf $\mathrm{N}$ and dry matter variables, despite the proximity of its values with those obtained by NDVI and SAVI indices.

This again demonstrates greater potential of the use of green band, when compared to the red band, to relate to the nutritional values obtained exactly in the leaves and detection of different 
nutritional levels. SILVA JUNIO et al. (2008) also observed that the GNDVI was one of the indices that most correlated with biomass and nitrogen doses in Brachiaria and may be considered a predictor of biomass.

SAVI index again obtained overall lower values of correlation with all the variables studied. This reinforces the fact of the low influence of the soil, because it is covered by forage.

When comparing the correlations between indices and SPAD, leaf $\mathrm{N}$ and dry matter from the first to the second phase, it was possible to verify that; overall, there was a decrease in the values of these coefficients. This fact was verified even with less time between image acquisition and collection of SPAD, leaf $\mathrm{N}$ and dry matter, and therefore less possibility in changing the number of leaves and leaf $\mathrm{N}$ content. This lower correlation probably resulted from the time change observed in this phase, which altered the effects of $\mathrm{N}$ on forage due to the decrease in temperature and lightness, making it difficult to discern between treatments.

It was also observed a decrease in index values from the first to the second phase. The same was observed by CUNHA (2004), who, when studying the spectral behavior in Tanzania grass, found a decrease in NDVI index values between periods. The author argued that this fact could be related to different environmental conditions present, such as minor incident solar radiation and lower temperatures, resulting in lower phytomass production and, consequently, low values of reflectance in the near infrared.

All values of vegetation indices adjusted to models of the first and/or second degree, at all phases and heights tested. This indicates that the canopy of the plants were influenced by $\mathrm{N}$ application, providing variations in the digital values for each treatment and that the height factor of the balloon was not limiting in the detection of different nutritional status in this forage.

In an experiment with Tanzania grass subjected to different levels of irrigation and nitrogen doses, CUNHA (2004) found that the spectral response of this type of forage altered according to variations in biomass quantity of canopy, caused by the influence of nitrogen doses. Furthermore, the author mentions that, in the canopy of this grass, it was possible to establish significant relations between spectral variables, obtained by remote sensing and agronomic variables. Thus, spectral parameters may serve as descriptors of vigor conditions and development of forage.

\section{CONCLUSIONS}

The remote sensing system with helium gas balloon at different heights generated vegetation indices capable of detecting variation in nutritional status in Brachiaria decumbent.

The use of the green band in the normalized difference vegetation index was more efficient in relation to the leaf nutritional estimate, with leaf $\mathrm{N}$ content and dry matter yield than the use of the red band.

In the first and second phase of the experiment, GNDVI was the index that best correlated with SPAD, leaf $\mathrm{N}$ and dry matter in the four heights tested.

The height of $30 \mathrm{~m}$ stood out with the highest correlations between the indices and SPAD, leaf $\mathrm{N}$ and dry matter in the first experimental phase.

\section{ACKNOWLEDGEMENTS}

To the Coordination of Improvement of Higher Education Personnel (CAPES), the Foundation for Research Support of the State of Minas Gerais (FAPEMIG), and the National Council for Scientific and Technological Development (CNPq) for funding this research and for the Research Grants to the authors. 


\section{REFERENCES}

ALVIM, M. J.; XAVIER, D. F.; BOTREL, M. A.; MARTINS, C. E. Resposta do coast-cross (Cynodon dactylon (L.) Pers.) a Diferentes Doses de Nitrogênio e Intervalos de Cortes. Revista Brasileira de Zootecnia, Viçosa-MG, v. 27, n. 5, p. 833-840, 1998.

BARCELLOS, A. O.; RAMOS, A. K. B.; VILELA, L.; MARTHA JUNIOR, G. B. Sustentabilidade da produção animal baseada em pastagens consorciadas e no emprego de leguminosas exclusivas, na forma de banco de proteína, nos trópicos brasileiros. Revista Brasileira de Zootecnia, ViçosaMG, v. 37, suplemento especial, p.51-67, 2008.

BEERI, O.; PHILLIPS, R.; HENDRICKSON, J.; FRANK, A. B.; KRONBERG, S. Estimating forage quantity and quality using aerial hyperspectral imagery for northern mixed-grass prairie. Remote Sensing of Environment, New York, v. 110, n. 2, p. 216-225, 2007.

CANTARUTTI, R. B.; MARTINS, C. E.; CARVALHO, M. M.; FONSECA, D. M.; ARRUDA, M. L.; VILELA, H.; OLIVEIRA, F. T. T. Pastagens. In: RIBEIRO, A. C.; GUIMARÃES, P. T. G.; ALVAREZ, V. H. Recomendações para o Uso de Corretivos e Fertilizantes em Minas Gerais - $5^{\text {a }}$ Aproximação. Viçosa: UFV, 1999. p. 332-341.

CUNHA, C. A. H. Relação entre comportamento espectral, índice de área foliar e produção de matéria seca em capim Tanzânia submetido a diferentes níveis de irrigação e doses de nitrogênio. 2004. 154 f. Dissertação (Doutorado em Agronomia) - Escola Superior de Agricultura "Luiz de Queiroz”, Universidade de São Paulo, Piracicaba, 2004.

DOUGHERTY, C.T.; RHYKERD, C.L. The role of nitrogen in forage-animal production. In: HEATH, M.E.; BARNES, R.F.; METCALFE, D.S. (Eds.) Forages: the science of grassland agriculture. 5th ed. Iowa: State University, 1985. p.318-325.

EPIPHANIO, J. C. N.; GLERIANI, J. M.; FORMAGGIO, A. R.; RUDORFF, B. F. T. Índices de vegetação no sensoriamento remoto da cultura do feijão. Pesuisa Agropecuária Brasileira, Brasília, v. 31, n.6, p. 445-454, jun. 1996.

FAGUNDES, J. L.; MOREIRA, A. L.; FREITAS, A. W. de P.; ZONTA, A.; HENRICHS, R.; ROCHA, F. C.; BACKES, A. A.; VIEIRA, J. S. Capacidade de suporte de pastagens de capimtifton 85 adubado com nitrogênio manejadas em lotação contínua com ovinos. Revista Brasileira de Zootecnia, Viçosa-MG, v. 40, n. 12, p. 2651-2657, 2011.

FAVA, F.; COLOMBO, R.; BOCCHI, S.; MERONI, M.; SITZIA, M.; FOIS, N.; ZUCCA, C. Identification of hyperspectral vegetation indices for Mediterranean pasture characterization. International Journal of Applied Earth Observation and Geoinformation, Eschede, v. 11, n. 4, p. 233-243, 2009.

GARCEZ NETO, A. F.; NASCIMENTO JUNIOR, D.; REGAZZI, A. J.; FONSECA, D. M.; MOSQUIM, P. R.; GOBBI, K, F. Respostas Morfogênicas e Estruturais de Panicum maximum cv. Mombaça sob diferentes Níveis de Adubação Nitrogenada e Alturas de Corte. Revista Brasileira de Zootecnia, Viçosa-MG, v. 31, n. 5, p. 1890-1900, 2002.

GITELSON, A. A.; KAUFMAN, Y. J.; MERZLYAK, M. N. Use of a green channel in remote sensing of global vegetation from EOS-MODIS. Remote Sensing of Environment, New York, v.58, p.289-298, 1996.

GITELSON, A.A. Wide dynamic range vegetation index for remote quantification of biophysical characteristics of vegetation. Journal Plant Physiology, Stuttgart, v.161, p.165-173, 2004.

HUETE, A. R. A soil ajusted vegetation index (SAVI). Remote Sensing Environment, New York, v.25, p.295-309, 1988.

JU, C. H.; TIAN, Y. C.; YAO, X.; CAO, W. X.; ZHU, Y.; HANNAWAY, D. Estimating leaf chlorophyll content using red edge parameters. Pedosphere, v. 20, n. 5, p. 633-644, 2010. 
MALAVOLTA, E.; LIEM, TH.; PRIMAVESI, A.C.P.A. Exigências nutricionais das plantas forrageiras. In: MATTOS, H.B.; WERNER, J.C.; YAMADA, T.; MALAVOLTA, E. Calagem e adubação de pastagens. Piracicaba: Associação Brasileira para Pesquisa de Potassa e do Fosfato, 1986. p. 31-76.

NUMATA, I.; ROBERTS, D. A.; CHADWICK, O. A.; SCHIMEL, J. P.; GALVÃO, L. S.; SOARES, J. V. Evaluation of hyperspectral data for pasture estimate in the Brazilian Amazon using field and imaging spectrometers. Remote Sensing of Environment, New York, v. 112, n. 4, p. 15691583, 2008.

PONZONI, F. J.; SHIMABUKURO, Y. E. Sensoriamento remoto no estudo da vegetação. São José dos Campos: INPE, 2007. 127 p.

RAMBO, L.; MA, B. L.; XIONH, Y.; SILVIA, P. R. F. Leaf and canopy optical characteristics as crop-N-status indicators for field nitrogen management in corn. Journal of Plant Nutrition and Soil Science, Temuco, v. 173, n. 3, p. 434-443, 2010.

ROUSE, J. W.; HAAS, R. H.; SCHELL, J. A.; DEERING, D. W; HARLAN, J. C. Monitoring the vernal advancement of retrogradation (greenwave effect) of natural vegetation. Greenbelt: NASA/GSFC, Type III, Final Report, 1974. 371 p.

SAMBORSKI, S. M.; TREMBLAY, N.; FALLON, E. Strategies to Make Use of Plant SensorsBased Diagnostic Information for Nitrogen Recommendations. Agronomy Journal, Madison, v. 101, n. 4, p. 800-816, 2009.

SANDMEIER, S.; MULLER, C.; HOSGOOD, B.; ANDREOLI, G. Physical Mechanisms in Hyperspectral BRDF Data of Grass and Watercress. Remote Sensing of Environment, New Yrok, v. 66, p. 222-233, 1998.

SERRANO, L.; FILELLA, I.; PEÑUELAS, J. Remote Sensing of Biomass and Yield of Winter Wheat under Different Nitrogen Supplies. Crop Science, Madison, v. 40, p. 723-731, 2000.

SILVA JÚNIOR, M. C.; PINTO, F. A. C.; FONSECA, D. M.; QUEIROZ, D. M; MACIEL, B. F. Detecção do efeito da adubação nitrogenada em Brachiaria decumbens Stapf. Utilizando um sistema de sensoriamento remoto. Revista Brasileira de Zootecnia, Viçosa-MG, v.37, n.3, p.411419, 2008.

SOBER. Sociedade Brasileira de Economia, Administração de Sociologia Rural. 2009. Disponível em: < http://www.sober.org.br/palestra/13/356.pdf>. Acesso em: 25 nov. 2011.

SOLARI, F.; SHANAHAN, J.; FERGUSON, R.; SCHEPERS, J. GITELSON, A. Active Sensor Refl ectance Measurements of Corn Nitrogen Status and Yield Potential. Agronomy Journal, Madison, v. 100, n. 3, p. 571-579, 2008.

VIDERE DESIGN. STH-DCSG-VAR/-C Stereo Head User`s Manual. Califórnia, 2005. 27 p.

WALTER-SHEA, E. A.; PRIVETTE, J.; CORNELL, D.; MESARCH, M. A.; HAYS, C. J.

Relations between directional spectral vegetation indices and leaf area and absorbed radiation in Alfalfa. Remote Sensing of Environment, New York, v. 61, p. 162-177, 1997.

WU, C.; NIU, Z.; TANG, Q.; HUANG, W. Estimating chlorophyll content from hyperspectral vegetation indices: Modeling and validation. Agricultural and Forest Meteorology, Amsterdam, v. 148, p. 1230-1241, 2008.

XIE, Y.; SHA, Z.; YU, M. Remote sensing imagery in vegetation mapping: a review. Journal of Plant Ecology, Oxford, v. 1, n. 1, p. 9-23, 2008. 